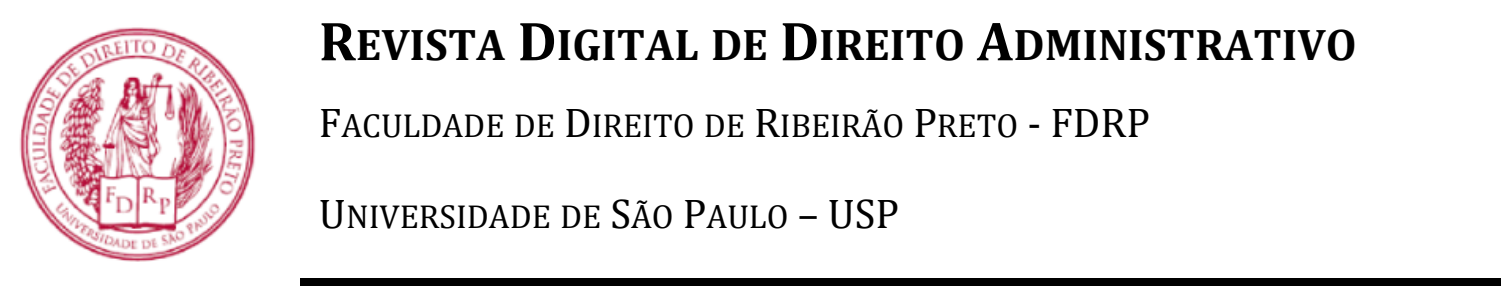

Seção: Artigos Científicos

\title{
Limites do controle do TCU sobre os atos discricionários das agências reguladoras
}

\author{
Limits of Brazilian Federal Court of Accounts (TCU) control over discretionary acts of regulatory \\ agencies
}

Heloisa Rodrigues da Rocha

Resumo: 0 presente artigo pretende analisar os limites do controle externo realizado pelo Tribunal de Contas da União (TCU) sobre os atos administrativos discricionários das agências reguladoras. Observa-se que esse conceito de discricionariedade evoluiu durante os três últimos séculos no Brasil. Desde o século XIX e até hoje, há quem defenda a impossibilidade do controle externo, judicial ou administrativo, sobre o mérito desses atos. Por outro lado, há quem defenda que não podem existir atos não sujeitos a qualquer tipo de controle. Análises empíricas e normativas demonstram que o TCU segue a teoria majoritária moderna, que permite o controle dos atos dentro de certos limites. Assim, apesar de existir um espaço de discricionariedade para a tomada de algumas decisões pelos gestores, é imprescindível que tais atos obedeçam aos limites legais e constitucionais, visando proteger a força normativa da Constituição e a própria Democracia.

Palavras-chave: controle externo; agências reguladoras; discricionariedade.

\begin{abstract}
This paper intends to analyze the limits of the external control performed by Brazilian Federal Court of Accounts (TCU) over discretionary administrative acts of regulatory agencies. It can be seen that the discretionary concept has evolved during the last three centuries in Brazil. Since the $19^{\text {th }}$ century e even nowadays, there are people who advocate for the impossibility of external control, be it administrative or judicial, over the core of these acts. On the other hand, there are people who defend that it cannot exist acts that are not subject to any kind of control. Normative and empirical studies demonstrate that TCU follows the most accepted theory, which allows the acts control inside certain limits. Therefore, even though exists a discretionary space for some decisions making by the public administrators, it is indispensable that these acts obey the constitutional and legal limits, in order to protect the normative power of the Constitution and even the Democracy.
\end{abstract}

Keywords: external control; regulatory agencies; discretionary.

Disponível no URL: www.revistas.usp.br/rdda

DOI: http://dx.doi.org/10.11606/issn.2319-0558.v7n2p37-59 


\section{LIMITES DO CONTROLE DO TCU SOBRE OS ATOS DISCRICIONÁRIOS DAS AGÊNCIAS REGULADORAS}

Heloisa Rodrigues da ROCHA*

Quando vista como mistério e, em certa medida, religião, a discricionariedade pode ser levada ao fanatismo.

Georges Abboud (2014, nota do autor)

Sumário: 1 Introdução; 2 Definição de discricionariedade administrativa; 2.1 Conceito clássico de discricionariedade administrativa; 2.2 Conceito moderno de discricionariedade administrativa; 2.3 Conceito crítico de discricionariedade administrativa; 3 Limites para o Controle do Tribunal de Contas da União sobre atos discricionários das agências reguladoras; $4 \mathrm{~A}$ Lei 13.655/2018 e seus efeitos no ordenamento jurídico; 5 Conclusão; 6 Referências bibliográficas

\section{Introdução}

0 exercício do controle externo realizado pelo TCU tem sofrido diversas modificações ao longo do tempo, especialmente após a Constituição Federal de 1988, que ampliou as atribuições e o escopo de atuação dos Tribunais de Contas no país. Não obstante, mesmo passados mais de trinta anos, ainda existem críticas e discussões acerca do limite de competência de tais órgãos.

Um dos pontos controvertidos para parte da doutrina é o controle realizado sobre os atos discricionários. Isso é ainda mais questionado quando se trata dos atos das agências reguladoras, pela sua própria natureza de mais independência e de lidar com temas mais técnicos.

0 presente artigo dedica-se a analisar esses limites, partindo de um panorama dos conceitos de discricionariedade, de forma a permitir a compreensão dos parâmetros de controle do TCU sobre as agências reguladoras que são atualmente adotados. Toda essa abordagem é feita sob a ótica anterior à Lei 13.655/2018, razão pela qual a última seção do artigo destina-se a repensar esses limites em face das alterações provocadas por esse normativo no Direito brasileiro.

\footnotetext{
* Especialista em Orçamento Público por ILB/Senado Federal. Especialista em Direito Digital e Compliance por Ibmec/Damásio. Graduanda em Direito por IDP. Servidora pública federal desde 2009.
} 


\section{Definição de discricionariedade administrativa}

No Direito Administrativo, o conceito de discricionariedade está associado ao poder discricionário da administração pública, isto é, na discricionariedade dos gestores para atuar em determinadas situações e temas.

Em que pese existirem semelhanças, há muitas diferenças entre a discricionariedade administrativa e a chamada discricionariedade judicial ou interpretativa. De acordo com Lênio Streck (2017, p. 55), a segunda "refere-se a um espaço a partir do qual o julgador estaria legitimado a criar a solução adequada para o caso que lhe foi apresentado a julgamento" e é objeto de estudo da Teoria do Direito.

A grande diferença entre discricionariedade administrativa e judicial, na visão de Streck (2017, p. 55) é que, na primeira, o "administrador está autorizado pela lei a eleger os meios necessários para determinação dos fins por ela estabelecidos", enquanto, na segunda, "o julgador efetivamente cria uma regulação para o caso que, antes de sua decisão, não encontrava respaldo no Direito da comunidade política".

Streck $(2017$, p. 56, 58) observa que a "discricionariedade judicial abre espaço para arbitrariedades", justamente por causa da "falta de controle conteudístico" de ambas. Assim, discricionariedade "nada mais é do que uma abertura criada no sistema para legitimar, de forma velada, uma arbitrariedade, não mais cometida pelo administrador [déspota do pré-Estado Liberal], mas pelo Judiciário".

Isso é ainda mais grave no Brasil, pois, conforme exposto pelo autor (STRECK, 2017, p. 57), os juristas brasileiros apropriam-se de qualquer espaço de sentido para exercitar a subjetividade do intérprete, incluídos os casos em que esse espaço é reduzido ou nem sequer existe.

Essa contundente crítica dirigida à maneira como a discricionariedade judicial é utilizada, especialmente no Brasil, é similar a críticas feitas com respeito à discricionariedade administrativa. Georges Abboud, por exemplo, afirma (2014, nota do autor) que "de nada adianta uma Constituição democrática e boas leis se, ao final, a administração puder decidir por conveniência e oportunidade e o juiz de acordo com a sua consciência".

Tal discussão será oportunamente retomada, não sem antes ser feita uma análise mais detida acerca da conceituação da discricionariedade administrativa ao longo do tempo, permitindo observá-la sob aspectos diferentes, mas complementares.

Maria Sylvia Zanella Di Pietro (2001, p. 14) sintetiza o desenvolvimento desse conceito:

Estudando-se a evolução da Administração Pública a partir do Estado de Polícia, verifica-se que se partiu de uma ideia de discricionariedade ampla - sinônimo de arbítrio e própria das monarquias absolutas, em que os atos da Administração não eram 
sindicáveis perante o Judiciário - para passar-se a uma fase, já no Estado de Direito, em que a discricionariedade, assim entendida, ficou reduzida a certo tipo de atos; e chegou-se a uma terceira fase em que praticamente desapareceu essa ideia de discricionariedade e esta surgiu como poder jurídico, ou seja, limitado pela lei. (sem grifos no original).

Para os propósitos do presente artigo, cabe analisar, com mais detalhes, essas duas últimas conceituações, elaboradas sob a égide do Estado de Direito, acrescentando uma terceira mais recente e crítica.

\subsection{Conceito clássico de discricionariedade administrativa}

A visão tradicional ou clássica da discricionariedade é a de que configuraria uma escolha ou opção para o agente, dentre as diversas possíveis, e que deveria ser exercida quando a lei assim o permitisse. Tal instituto existiria justamente porque é impossível a lei prever todas as decisões e ações possíveis no caso concreto e, mesmo que fosse possível, esta não seria a melhor alternativa em alguns casos, porque caberia ao agente avaliar as condições e decidir cada caso da forma mais adequada.

Celso Antônio Bandeira de Mello expõe esse conceito, com o intuito de posteriormente desconstruí-lo (2007, p. 15-16):

Sabe-se que a ideia corrente da discricionariedade, entretanto, enfatiza a noção de "poder". Enfatiza, de conseguinte, a presunção de que o agente público, quando a lei lhe outorga aquilo que se denomina discricionariedade, dispõe de um poder para fazer escolhas livres, na suposição de que dentre as alternativas comportadas pela norma em abstrato, quaisquer delas são de indiferente aplicação no caso concreto.

Di Pietro (2001, p. 14) destaca que a maneira com que o princípio da legalidade é compreendido influi diretamente na extensão da discricionariedade admitida. Em uma época em que "a lei é vista dentro de um sistema lógico-jurídico, despido de qualquer conteúdo axiológico", haverá maior discricionariedade, uma vez que os atos devem obediência meramente em sentido formal à lei. 0 controle do Poder Judiciário também será adstrito a esses limites formais.

A jurista aponta (DI PIETRO, 2014, p. 27) que se trata de um resquício do Estado de Polícia, vigente nas monarquias absolutistas, que configurava uma esfera de atuação da Administração Pública livre de qualquer controle judicial.

Uma das implicações dessa definição é que o mérito do ato discricionário seria um espaço inviolável, não sujeito ao controle de outro órgão exterior, seja administrativo ou judicial, sob pena de invadir as competências exclusivas do gestor. 
Nesse paradigma, qualquer tipo de controle deveria restringir-se aos aspectos formais do ato discricionários, como competência e forma.

Uma evidência da longevidade dessa visão no Direito brasileiro (CASTRO, 2006, p. 170-171) é a Lei 221, de 20/11/1894, que tratava da organização da Justiça Federal, no início da República. Ao disciplinar que os atos administrativos estavam sujeitos ao controle judicial, o normativo estabelecia expressamente a proibição de que os juízes analisassem o mérito administrativo desses atos, especificamente sob o ponto de vista de conveniência e oportunidade (BRASIL, 1894):

Lei no 221, de 20/11/1894

Art. 13. Os juizes e tribunaes federaes processarão e julgarão as causas que se fundarem na lesão de direitos individuaes por actos ou decisão das autoridades administrativas da União.

\section{$(\ldots)$}

§ 9o Verificando a autoridade judiciaria que o acto ou resolução em questão é illegal, o annullará no todo ou em parte, para o fim de assegurar o direito do autor.

a) Consideram-se illegaes os actos ou decisões administrativas em razão da não applicação ou indevida applicação do direito vigente. A autoridade judiciaria fundar-se-ha em razões juridicas, abstendo-se de apreciar o merecimento de actos administrativos, sob o ponto de vista de sua conveniencia ou opportunidade;

b) A medida administrativa tomada em virtude de uma faculdade ou poder discricionario sómente será havida por illegal em razão da incompetencia da autoridade respectiva ou do excesso de poder. (sem grifos no original)

Castro aponta (2006, p. 171-172) que isso representa uma distorção institucional. Sustenta que esse é um exemplo da "excessiva deferência de nossa ordem jurídica às competências discricionárias do Poder Público, notadamente no campo do poder de polícia", bem como "revela a idolatria do Estado no Brasil e sua feição autoritária, em cujo âmago descansa a proeminência e a incontrastabilidade dos agentes governamentais em face do cidadão comum".

Ainda assim, há quem defenda esse conceito de discricionariedade nos dias atuais, insurgindo-se contra qualquer tipo de controle de mérito por parte de órgãos judiciais e administrativos, incluindo os Tribunais de Contas.

Na visão de Diogo de Figueiredo Moreira Neto (1991, p. 57), esse conceito é motivado por uma "teimosa e distorcida concepção de separação de Poderes que 
'impediria' que um Poder do Estado obstasse o livre exercício da competência 'exclusiva' de outro".

Também há quem admita alguns temperamentos nessa insindicabilidade do mérito, contudo resguardando um espaço impenetrável pelo controle.

Por exemplo, com relação ao controle judicial e administrativo da discricionariedade dos atos das agências reguladoras, Schirato sustenta (2003, p. 264) que o controle externo dos Tribunais de Contas (TCs) deveria focar na verificação da legalidade formal, bem como deveria restringir sua análise subsidiária da legalidade material "apenas sobre um controle de razoabilidade, proporcionalidade, alcance da finalidade legalmente prevista e motivação".

Percebe-se que a visão clássica ou tradicional da discricionariedade é uma definição calcada, consciente ou inconscientemente, em ideias e conceitos anteriores ao Constitucionalismo, atribuindo um poder considerável nas mãos do gestor e que não é suscetível de questionamento ou fiscalização. Tamanha liberdade aparenta ser incompatível com o que preconiza o ordenamento vigente e até com o próprio Estado Democrático de Direito.

Isso motivou o desenvolvimento de outro conceito de discricionariedade, que é objeto da próxima seção.

\subsection{Conceito moderno de discricionariedade administrativa}

Essa definição de discricionariedade parte de uma premissa que decorre da definição de um Estado Constitucional e Democrático de Direito: não é admissível que existam redutos estatais acima e fora de qualquer tipo de controle legal.

Portanto, ainda que haja diferentes opções ou alternativas legalmente possíveis, essa escolha não só pode, como deve ser objeto de controle judicial e administrativo, de maneira a garantir que tenha sido feita em estrita observância dos limites legais e em consonância com as finalidades e os objetivos previstos na legislação.

Celso Antônio Bandeira de Mello (2007, p. 14) esclarece que a relação entre a Administração Pública e a lei é não apenas de não contradição, como principalmente de subsunção. Isso, porque toda a atuação administrativa, incluindo o uso do poder discricionário, deve obedecer aos limites legais, estando estritamente subordinado à lei. Assim, um comportamento administrativo que não estivesse autorizado pela lei ou que a contrariasse seria arbítrio, isto é, "abuso intolerável, pois discricionariedade e arbitrariedade são noções radicalmente distintas".

Di Pietro acrescenta que a "função administrativa é parcial, no sentido de que a Administração Pública é parte interessada em todas as decisões que adota". Por tal razão, sempre é cabível o "controle jurisdicional, exercido por órgão imparcial, que 
assume a posição de terceiro perante os litígios que decide" (DI PIETRO, 2001, p. 13).

Um dos princípios basilares do Estado de Direito é justamente que todos devem obedecer à legislação, inclusive o próprio Estado. Por isso, Celso Antônio Bandeira de Mello (2007, p. 11) defende que nenhum agente estatal pode fugir desse arcabouço normativo, esteja ou não exercendo poder discricionário.

Di Pietro pontua que (2001, p. 14) "a discricionariedade constitui a chave do equilíbrio entre as prerrogativas públicas e os direitos individuais. Quanto maior a extensão da discricionariedade, mais risco correm às liberdades do cidadão".

Celso Antônio Bandeira de Mello prossegue diferenciando o conceito de poder do conceito de dever, que em Direito Privado estaria melhor explicitado na figura da tutela, da curatela e do pátrio poder. Nesses instrumentos, a finalidade da atuação deve ser em benefício do tutelado, do curatelado e do filho, e não em prol dos interesses próprios do tutor, curador ou pai. O doutrinador (MELLO, 2007, p. 14) enxerga claramente que existe um dever desses atores agirem visando o bem-estar de quem estão protegendo e substituindo.

No Direito Administrativo, o raciocínio tem de ser o mesmo. 0 poder discricionário, para o eminente jurista, não é exatamente um poder da Administração Pública, mas sim um dever, uma finalidade a ser cumprida, que traz consigo um poder instrumental como mera decorrência para que se cumpra o dever. Celso Antônio Bandeira de Mello (2007, p. 15) conclui que o poder discricionário corresponde ao cumprimento do dever legal de atingir determinada finalidade. No mesmo sentido, Giussepe Fazio afirma que "a emanação de um ato discricionário comporta o exercício de um dever tendo por conteúdo um poder" (1971, p. 16, apud MELLO, p. 15).

Não obstante, Celso Antônio Bandeira de Mello admite que existem casos em que mais de uma opção é igualmente válida, especialmente quando se trata de conceitos vagos ou fluidos, de forma que não se poderia apontar uma transgressão legal quando o agente adotasse uma interpretação razoável dentre as possíveis. Teria agido, assim, "dentro de uma liberdade intelectiva que, in concreto, o direito lhe facultava" (2007, p. 23).

Dessa forma, Celso Antônio Bandeira de Mello (2007, p. 27-28) defende que o controle judicial sobre os atos administrativos verifique se a interpretação da lei feita pela Administração Pública não transborda os limites da moldura normativa (KELSEN, 2008, p. 350-351) e se "a opção de conveniência e oportunidade se fez sem desvio de poder, isto é, obsequiosa às finalidades da lei". 0 jurista destaca que, em muitos casos, há um entrelaçamento entre esses dois requisitos, posto que, para avaliar se determinada ação adotada era conveniente e oportuna porquanto facultada pela lei, é necessário primeiramente saber se a situação correspondia ao termo vago. Por exemplo, se a lei permite adotar alguma providência em situações 
de urgência, avaliar a legalidade das ações tomadas depende da definição se era ou não um caso de urgência.

Assim, Celso Antônio Bandeira de Mello (2007, p. 88-89) conclui que, conforme entendimento majoritário da doutrina, o controle dos atos administrativos estendese inevitavelmente à análise dos motivos como requisito de legitimidade. Por isso, a motivação dos atos que comportem alguma discricionariedade é obrigatória (MELLO, 2007, p. 105). Deste modo, Celso Antônio Bandeira de Mello sintetiza suas posições no seguinte conceito de discricionariedade (2007, p. 48):

Discricionariedade é, portanto, a margem de liberdade que remanesça ao administrador para eleger, segundo critérios consistentes de razoabilidade, um, dentre pelo menos dois comportamentos cabíveis, perante cada caso concreto, a fim de cumprir o dever de adotar a solução mais adequada à satisfação da finalidade legal, quando, por força da fluidez das expressões da lei ou da liberdade conferida no mandamento, dela não se possa extrair objetivamente, uma solução unívoca para a situação vertente.

Por sua vez, Di Pietro define discricionariedade como (2001, p. 67) "a faculdade que a lei confere à Administração para apreciar o caso concreto, segundo critérios de oportunidade e conveniência, e escolher uma dentre duas ou mais soluções, todas válidas perante o direito".

A professora também aponta (DI PIETRO, 2001, p. 15) que, no atual paradigma, para se delimitar a discricionariedade conferida pela lei, é essencial considerar, além do princípio da legalidade em sua feição axiológica, os princípios gerais do Direito e os princípios da moralidade, da razoabilidade, do interesse público e da motivação. Dito de outra forma (DI PIETRO, 2001, p. 46), a discricionariedade administrativa não é limitada somente pela lei, mas também pela ideia de justiça, com todos os valores que lhe são inerentes, e por todos os princípios que consagram valores expressos ou implícitos na Constituição relacionados à liberdade, igualdade, segurança, desenvolvimento e bem-estar.

Contudo, a eminente professora faz a ressalva de que, no Brasil, esse controle da discricionariedade pelo Poder Judiciário é problemático por vários aspectos (DI PIETRO, 2001, p. 38-39). Primeiro, pela dependência do Judiciário em relação ao Executivo, que, na visão da jurista, impede uma análise verdadeiramente imparcial e distante de influências políticas. Segundo, porque haveria um "despreparo dos magistrados em relação ao Direito Público, em especial o administrativo", resultando em um apego excessivo ao formalismo da lei, sem maiores preocupações com o Direito, com as tensões sociais ou com a construção de uma jurisprudência que vise a estabelecer e fortalecer os princípios que devem delimitar a discricionariedade administrativa, como ocorre em países de contencioso administrativo como a França. 
Quanto a este ponto, Moreira Neto ressalta (1991, p. 58) que a ausência de um sistema independente de contencioso administrativo no país não deve inibir o Poder Judiciário de analisar e controlar a discricionariedade administrativa exatamente porque "não há outra solução para a defesa do administrado", ou seja, se os órgãos julgadores recusarem-se a atuar alegando ser matéria discricionária, "inúmeras formas de violação indireta da legalidade" ficariam "irremediavelmente excluídas do controle jurisdicional, o que seria inadmissível" por contrariar o art. 5ํ, inciso XXXV, da Constituição.

Em que pese reconhecer que existem dificuldades em entender onde termina a legalidade e onde começa a discricionariedade administrativa, Di Pietro afirma (2001, p. 38) que o Poder Judiciário brasileiro acaba acomodando-se com essas dificuldades e detendo sua atuação no "mal definido 'mérito' da atuação administrativa, permitindo que prevaleça o arbítrio administrativo onde deveria haver discricionariedade exercida nos limites estabelecidos lei".

Di Pietro esclarece (2001, p. 130) que, em sua opinião, ao Judiciário de fato é vedado o controle do mérito do ato administrativo, entendido como o "aspecto político" que abrange a conveniência e a oportunidade, bem como critérios de justiça e igualdade (DI PIETRO, 2001, p. 66). Porém, muitas vezes, esse mérito é usado como "escudo à atuação judicial em casos que, na realidade, envolvem questões de legalidade e moralidade administrativas".

Por isso, a jurista sustenta (DI PIETRO, 2001, p. 130) que é preciso definir e respeitar os limites da discricionariedade "para impedir as arbitrariedades que a Administração Pública pratica sob o pretexto de agir discricionariamente em matéria de mérito".

Moreira Neto reafirma (1991, p. 62-63) esse entendimento ao consignar que o papel do Judiciário é verificar a conformidade do ato discricionário com seus limites, examinando não o mérito em si, mas no que o exorbita. Ainda acrescenta que é indispensável que o juiz também considere, em sua apreciação, os fatos, pois somente a plena cognição deles permite definir o que é sindicável e o que não é (MOREIRA NETO, 1991, p. 59).

Em obra mais recente, Di Pietro (2017, p. 162) destaca que, sob alguns aspectos, tem sido observado um controle mais efetivo dos atos discricionários pelo Poder Judiciário nas últimas décadas, mas que isso ainda é insuficiente em face dos desafios que o tema impõe.

Cabe ressaltar que mesmo nos Estados Unidos há o reconhecimento da doutrina e da jurisprudência de que é possível a "revisibilidade dos atos ditos discricionários sempre que os mesmos incorrerem em abuso de discrição (abuse of discretion), mediante violação de direito explícita ou implicitamente assegurado na Constituição" (CASTRO, 2006, p. 169). 
Outro ponto destacado por Di Pietro (2001, p. 39-40) é o surgimento da tecno(buro)cracia, que seria um micropoder, inserido dentro do Poder Executivo, fruto do aumento da complexidade dos problemas sociais e econômicos. Ao concentrar decisões cada vez mais relevantes e complexas, esse micropoder atrai a atuação dos grupos de lobby, desloca as discussões que tradicionalmente deveriam ocorrer no Parlamento e dificulta o exercício de controle jurisdicional efetivo de suas ações. Tal comportamento afeta as relações entre os poderes e o exercício da soberania, "desequilibrando a função de controle exercida pelo Legislativo e pelo Judiciário".

Nas palavras de Tércio Sampaio Ferraz (apud DI PIETRO, 2001, p. 40), essa situação permite que o Poder Executivo assuma "a fachada de um ator aparentemente respaldado em uma neutralidade tecnológica de presumida eficiência".

Tendo por ponto de partida essas críticas, alguns autores defendem um conceito ainda mais restrito de discricionariedade, como é tratado a seguir.

\subsection{Conceito crítico de discricionariedade administrativa}

O campo do Direito como um todo passou por significativas transformações ao longo do século XX, em todo o mundo. Revistando o tema da discricionariedade administrativa e judicial à luz das ideias e dos conceitos desenvolvidos por notórios juristas no século XX e no início do século XXI, alguns autores propuseram uma nova maneira de definir e lidar com a discricionariedade.

Após realizar um extenso estudo acerca do tema, Georges Abboud aponta (2014, introdução) que a discricionariedade "é instituto jurídico que constantemente se metamorfoseia para conferir elasticidade conteudística às decisões", bem como é a que "faz caber qualquer conceito na decisão". Por conta disso, na visão do jurista, a Administração Pública e o Judiciário criariam uma blindagem, composta pelos limites da discricionariedade administrativa e do juízo discricionário, para não se submeterem a um teste qualitativo que verifique a constitucionalidade e a legalidade de seus atos e decisões.

Abboud sustenta (2014, introdução) que, independentemente de ser judicial ou administrativa, todas as manifestações da discricionariedade têm como elemento comum a aleatoriedade, entendida como "fuga do jurídico". Dito de outra forma, o autor defende que toda decisão justificada como discricionária é, na realidade, uma escolha feita para que não seja haja uma decisão com base em parâmetros jurídicos.

Nesse trabalho, o jurista avança e propõe uma classificação original para a discricionariedade administrativa, dividindo em cinco grandes modelos (ABBOUD, 2014, introdução): 
a) interpretativa - em que o ato discricionário é classificado como oposto ao ato vinculado. Somente haveria interpretação na produção do primeiro;

b) optativa - a mais frequente, consistente na possibilidade de se escolher uma dentre diversas escolhas legítimas;

c) performática - com bases nos enunciados performáticos de Austin, classifica uma modalidade de discricionariedade que blinda o ato de qualquer revisão jurisdicional, porque assentado em enunciados performáticos, os conhecidos interesse público e o critério de conveniência e oportunidade;

d) volitiva - ato administrativo se justifica por estar baseado na vontade da lei ou do administrador;

e) técnica - a utilização de critérios metajurídicos tornaria o ato insindicável, porque fundado em elementos técnicos.

A análise detalhada desses modelos leva ao autor a concluir que, para ser válido, um ato administrativo deve, obrigatoriamente, atender aos seguintes requisitos (ABBOUD, 2014, introdução): deve ter embasamento legal, ser proporcional, atender ao interesse social, ser exaustivamente fundamentado e ser passível de revisão judicial, inclusive em seu mérito. Ou seja, para Abboud (2014, introdução), a possibilidade de revisão do mérito dos atos administrativos por um órgão externo não só é legal e constitucionalmente admitida, como é indispensável. Não existe, no seu entendimento, um núcleo decisório insusceptível de posterior controle pelo Poder Judiciário.

Cabe destacar que o jurista não defende que todo e qualquer ato administrativo seja rediscutido na esfera judicial ou que o controle judicial deva ser prévio à prática dos atos da Administração Pública. Pelo contrário, o autor explica que "não haverá nenhum ganho democrático se admitirmos a transferência da discricionariedade administrativa para a esfera judicial", uma vez que os gestores públicos possuem essa competência constitucional de decidir (ABBOUD, 2014, introdução).

O que Abboud condena é a existência de zonas insindicáveis no âmbito dos atos administrativos, pois isso contraria a própria lógica de um Estado Constitucional. 0 autor lembra que o controle de constitucionalidade das leis evoluiu no último século para permitir que o conteúdo das leis também fosse objeto de sua análise, afastando-se do pensamento de que qualquer conteúdo poderá ser direito se estiver positivado em um normativo (ABBOUD, 2014, introdução).

O jurista sustenta que, da mesma forma, deve evoluir o controle dos atos administrativos, até para que o direito possa cumprir a sua função primordial. Em suma (ABBOUD, 2014, introdução):

Enfim, se o direito servir apenas para considerar como incorretas as decisões absurdas e ilegais, então o direito fracassou. Se toda 
decisão que fosse abarcada por um bom senso jurídico (sic) ${ }^{1}$ puder ser considerada legítima em nosso sistema, então, infelizmente, o direito serve para muito pouca coisa. Se o direito for utilizado apenas para apontar bizarrices, nosso projeto constitucional-democrático está fracassado.

Luiz Henrique Madalena também tem uma opinião mais crítica sobre a discricionariedade administrativa e a maneira como é utilizada pela Administração Pública. Para o autor (MADALENA, 2016, p. 209), "na atividade executiva, ou seja, administrativa, não há uma esfera política", "sob pena de total relativização do direito e do controle da atividade estatal, pela atribuição discricionária, ou seja, com margem de liberdade (efetivamente) ao intérprete, de instituir quantas dimensões políticas quiser e onde quiser".

Desta forma, os atos ditos discricionários que são genuinamente decisões administrativas "devem ser tidos como integralmente controláveis" (MADALENA, 2016, p. 222-223). Na visão do jurista, esse tipo de decisão não pode ficar no "âmbito da discricionariedade que não pode ser tocada pelo Judiciário ou qualquer outro ente de controle de própria atividade estatal de administração" (MADALENA, 2016, p. 210), exatamente para evitar que a discricionariedade seja utilizada para justificar condutas que atendam à legalidade formal, mas que visem a um resultado "contrário aos objetivos plasmados na Constituição" (MADALENA, 2016, p. 18).

Por fim, Madalena frisa que (2016, p. 228) a doutrina administrativista pátria, em vez de focar no controle da discricionariedade, "partiu para a obtenção de justificativas para a mesma, o que apenas serve para legitimar a ausência de controles".

\section{Limites para o Controle do Tribunal de Contas da União sobre atos discricionários das agências reguladoras}

O TCU foi criado no ano seguinte à proclamação da República, pelo Decreto nº 966A, de 7/11/1890. Seu desenho institucional variou significativamente ao longo desse período de quase 130 anos de existência (RIBEIRO, 2002, p. 61-92; MENEZES, 2015, p. 132). A Constituição Federal de 1988 ampliou o escopo de atuação da Corte de Contas, possibilitando a realização auditorias operacionais para avaliar aspectos de eficiência, economicidade e eficácia, além das tradicionais análises de conformidade legal (RIBEIRO, 2002, p. 80-82; MENEZES, 2015, p. 132-134).

Neste contexto, insere-se a fiscalização do Tribunal sobre as atividades finalísticas das agências reguladoras, que, por sua vez, abrangem o controle dos seus atos discricionários. Em palestra no ano de 2001, o Ministro do TCU Benjamin Zymler já sintetizava entendimento, que é consenso no Tribunal, de que a "análise da eficiência do ente regulador só é possível através da fiscalização das atividades fins da

\footnotetext{
${ }^{1}$ Expressão constante do texto original, como crítica do autor ao conceito discutível, ainda que popular, de "bom senso jurídico".
} 
agência reguladora, incluindo aí os contratos de concessão e permissão, além dos atos de autorização" (apud MENEZES, 2015, p. 134).

Destaque-se que o Tribunal não pode nem deseja substituir os jurisdicionados em suas atividades e competências, mas também não pode abster-se de realizar um controle finalístico, ou seja, mais do que apenas controle formal, "burocrático" ou das atividades-meio.

Até porque os Tribunais de Contas, por serem órgãos administrativos compostos por servidores de múltiplas formações profissionais, possuem capacidade técnica de analisar diretamente questões não-jurídicas, que podem ser excessivamente complexas a ponto de dificultar uma atuação tempestiva e efetiva do Poder Judiciário, como apontado por Di Pietro (2001, p. 38) e citado anteriormente.

Os magistrados, por excelência, possuem a capacitação e formação necessárias para analisar as questões de direito, porém não se espera que tenham o mesmo nível de proficiência para tratar, diretamente e por conta própria, da maioria das questões técnicas com que lidam as agências reguladoras e que muitas vezes são indissociáveis das decisões e dos atos jurídicos adotados.

Em que pese ser mais frequente no contexto regulatório, isso pode ocorrer em setores da Administração Pública direta. Tem-se, como exemplo recente, decisão acerca de contratação direta por inexigibilidade de licitação de serviço de banda larga por satélite em que o juiz afirmou que não poderia suspender a execução do contrato em sede de liminar por não ser capaz de avaliar as questões técnicas e constatar o fumis bonis iuris apenas com base em cognição sumária²

De forma diversa, ao analisar o mesmo objeto, o TCU entendeu ser cabível a suspensão imediata em face dos indícios de irregularidades identificados e referendou a proposta de medida cautelar da Ministra Relatora Ana Arraes. Tal diferença de entendimento deveu-se, entre outros pontos, ao fato de que a análise técnica do Tribunal fundamentou-se em elementos adicionais colhidos pela unidade técnica e

\footnotetext{
${ }^{2}$ Em sua decisão, o Juiz Federal Márcio Luiz Coelho de Freitas destacou que: “(...) a questão comporta, ao lado da decisão política, também há uma análise técnica relativa à melhor forma de implementar-se o programa objeto da decisão política. Ora, nesta matéria evidentemente carece este juízo de capacidade técnica para avaliar a correção das decisões adotadas pela Administração, inclusive quanto à alegada falta de capacidade operacional dos satélites atualmente em uso no Brasil ou quanto ao modelo de contratação. (...) A questão, por ser de natureza eminentemente técnica, depende de instrução processual para que efetivamente seja demonstrada a probabilidade do direito pleiteado. (...) quando se está diante de uma questão aberta e que admite mais de uma interpretação possível, deve ser adotada uma postura de autocontenção judicial, de modo a evitar-se o risco de substituição da conveniência do administrador pela do julgador. Assim, penso que somente em casos de evidente violação à lei é que o juiz poderá invalidar a posição adotada pela administração. Quando a questão a ser decidida se coloca em uma zona de incerteza, não deve ser deferida a medida, especialmente em sede de liminar". Decisão de 7/5/2018. Processo 1008123-57.2018.4.01.3400, ação civil pública na 9ạ Vara Federal da Seção Judiciária do Distrito Federal da Justiça Federal.
} 
no conhecimento especializado do setor que a área possui, devido ao fato de acompanhar e fiscalizar esses órgãos e entidades há décadas ${ }^{3}$.

Outro exemplo foi o recurso de apelação apreciado pelo Tribunal Regional Federal da 1a Região (TRF-1) acerca de ação civil pública em que a Agência Nacional das Telecomunicações (Anatel) e a União foram condenadas, entre outros pontos, a consolidar e apresentar as listas de bens reversíveis da concessão de telefonia fixa, incluindo as fibras óticas que compõem o chamado backhaul construído com recursos da telefonia fixa. Um dos principais fundamentos utilizados pelos magistrados para negar a procedência do recurso das condenadas foi o teor das irregularidades registradas no Acórdão 3.311/2015-TCU-Plenário, resultado da auditoria operacional realizada pelo TCU sobre a atuação da Anatel sobre o controle dos bens reversíveis ${ }^{4}$.

Se já há críticas ao excessivo ativismo judicial nas políticas públicas, ou seja, à atuação do Poder Judiciário substituindo a Administração Direta enquanto formuladora e executora de políticas públicas ${ }^{5}$, em matéria regulatória essa interferência pode ser ainda mais danosa.

Por outro lado, a própria CF garante que toda e qualquer lesão a direitos pode ser discutida no âmbito do Poder Judiciário, não podendo esse direito fundamental ser totalmente restringido no campo de atuação das agências reguladoras, seja porque a matéria é densa tecnicamente, complexa ou abriga-se no mérito administrativo de um ato dito discricionário.

\footnotetext{
${ }^{3} \mathrm{Em}$ seu Voto, a Ministra Ana Arraes esclareceu que "A (...) [unidade técnica do TCU] analisou os documentos e os dados contidos nestes autos em cotejo com informações obtidas por meio de diligências feitas no âmbito do processo (...) mediante o qual esse assunto já vinha sendo acompanhado pelo TCU, de forma que o presente exame não está adstrito somente ao objeto e aos termos da representação apresentada. Além dos apontamentos acerca da indevida inexigibilidade de licitação e direcionamento da contratação, foram detectados os seguintes indícios de irregularidades: (...). A (...) [unidade técnica do TCU], em pareceres uniformes, propôs seja adotada medida cautelar inaudita altera pars, com determinação ao (...) e à (...) para que suspendam a execução do Contrato (...) até que o TCU delibere sobre o mérito da matéria. 5. Manifesto-me de acordo com a unidade técnica, pelos motivos que irei expor na sequência". Acórdão 1.692/2018-TCU-Plenário, de 26/7/2018.

${ }^{4}$ Por exemplo, ao tratar do pedido da União para que fosse excluída do polo passivo da demanda, o Desembargador Federal Souza Prudente afirmou em seu Voto-Vogal que "a competência originária para explorar os serviços de telecomunicações no Brasil e dispor sobre a sua organização é da União Federal, que, nos termos da lei, utiliza-se instrumentalmente da Anatel, e que, diante das pupilas da investigação do TCU, não está cumprindo com o seu dever legal, e, portanto, eu não posso chegar a outra conclusão senão a de que a União tem interesse jurídico, econômico e financeiro e respeito ao povo brasileiro no presente feito". A auditoria do TCU também foi mencionada como fundamento no Voto do Desembargador Federal João Batista Moreira, relator do caso. Acórdão de 16/3/2016. Processo Apelação/Reexame Necessário no 0029346-30.2011.4.01.3400/DF no Tribunal Regional Federal da 1a Região.

${ }^{5}$ Para exemplos de textos que abordam essas críticas, ver SARMENTO, Daniel. A proteção judicial dos direitos sociais: alguns parâmetros ético-jurídicos, disponível em http://www.dsarmento.adv.br/content/3-publicacoes/17-a-protecao-judicial-dos-direitos-sociais-alguns-parametros-etico-juridicos/a-protecao-judicial-dos-direitos-sociais.alguns-parametros-etico-juridicos-daniel-sarmento.pdf, e BRANDÃO, Rodrigo. Constituição e Sociedade: judicialização da política, disponível em https://www.jota.info/opiniao-e-analise/artigos/constituicao-e-sociedade-judicializacao-da-politica-09122014.
} 
Encontrar o ponto de equilíbrio entre esses dois extremos é um desafio permanente para o Poder Judiciário, mas que não invalida nem interfere no controle a ser exercido pelos Tribunais de Contas. Pelo contrário, somente reforça a necessidade de que esse controle externo administrativo exista e funcione de forma efetiva e independente.

Além disso, as agências reguladoras não são subordinadas hierarquicamente aos seus Ministérios vinculados, então, os TCs, ao exercerem seu papel de accountability horizontal ${ }^{6}$, funcionam como uma importante instância técnica de controle das decisões das agências reguladoras. A possibilidade de que cidadãos e parlamentares façam denúncias e solicitações de fiscalizações aos TCs também reflete o importante papel desses Tribunais no auxílio ao controle social e parlamentar da atuação da Administração Pública.

Em obra dedicada exclusivamente ao tema do controle do TCU sobre as agências reguladoras, a pesquisadora Monique Menezes avaliou 292 decisões do Tribunal, tendo selecionado nove auditorias para analisar detidamente o impacto da atuação do TCU no setor regulado, e constatou que (MENEZES, 2015, p. 230-231) "foi possível observar ações das agências reguladoras, que eram excessivamente discricionárias e com pouca justificativa técnica formal, serem revisadas, a partir de determinações de auditorias da Corte de Contas".

Por isso, a autora argumenta que a atuação do Tribunal de Contas aumenta a credibilidade e a segurança da política regulatória, na medida em que inibe um "possível comportamento oportunista e discricionário das agências reguladoras", diminuindo as chances de captura dessas instituições pelas empresas do setor regulado (MENEZES, 2015, p. 37-38).

Isso ocorre, porque as agências reguladoras são entidades administrativas sujeitas aos mesmos problemas, fragilidades e idiossincrasias que permeiam todos os demais órgãos e entidades da Administração Pública brasileira.

Falhas na governança, conflitos na atribuição de competências entre as divisões internas e captura dos reguladores pelos agentes interessados são exemplos de

\footnotetext{
${ }^{6}$ Em uma Democracia, os governantes eleitos e os gestores devem prestar contas de sua atuação ao povo, de forma transparente, tempestiva e compreensível, para demonstrar a regularidade, a efetividade e a adequação de suas ações frente aos interesses e necessidades coletivas. Essa accountability manifesta-se sob duas formas distintas, porém complementares: controle vertical, exercido pelos eleitores individualmente, pela sociedade organizada e pelos meios de comunicação, e controle horizontal, de competência de todos os órgãos públicos e as entidades criados legal ou constitucionalmente para controlar a atuação governamental, como o Poder Legislativo, o Poder Judiciário, Tribunais e Comissões Eleitorais, Entidades de Auditoria, Bancos Centrais, Comissões de Direitos Humanos, Entidades Anticorrupção, entre outras. Nota-se que o controle horizontal pode ser exercido por órgãos diversos, que possuem diferentes graus de autonomia e de poder para analisar as áreas de atuação governamental, para determinar a correção das inconformidades e para sancionar os responsáveis. Cf. SHACTER, M. A Framework for Evaluating Institutions of Accountability. In: Fiscal Management. Editor: Anwar Shah. Washington DC: Banco Mundial. 2005. Disponível em http://siteresources.worldbank.org/PSGLP/Resources/FiscalManagement.pdf. p. 230-231. Acesso em 3/7/2017.
} 
problemas que podem minar a legalidade e a legitimidade de decisões finalísticas das agências reguladoras, resultando inclusive em expressivos danos financeiros ao Erário.

Nesse ponto, o controle do TCU é imprescindível e insubstituível. Nas palavras de Menezes (2015, p. 232), a "atuação do Tribunal é amparada constitucionalmente, dentro de um sistema de controle horizontal típico dos regimes democráticos, sendo parte integrante da accountability do processo de delegação de competência sobre uma área de política pública". Não por outro motivo, em diversos países, há instituições como o TCU exercendo o mesmo tipo de controle sobre as agências reguladoras locais, como o General Accountability Office (GA0) dos Estados Unidos e o National Audit Office (NAO) do Reino Unido (MENEZES, 2015, p. 145).

Algumas das críticas ao trabalho de controle externo do TCU sobre as atividades finalísticas das agências reguladoras advêm da falta de conhecimento específico sobre a forma de atuação do Tribunal e das características e condições especificas dos casos concretos.

Referindo-se tanto ao controle judicial quanto ao administrativo, Schirato (2003, p. 271) alega que há um "exagero na incidência do controle sobre as decisões regulatórias", causada por diversos fatores como a hipotética capacitação técnica inferior ou inexistente dos controladores, em comparação com os reguladores, e a suposta ausência, para o controlador, de "qualquer ônus em razão das consequências de sua decisão, colocando-o em uma situação muito confortável".

Tais críticas são infundadas e desmedidas, especialmente em relação ao TCU, notório pela capacitação técnica de seu corpo funcional e sua participação independente no processo decisório (RIBEIR0, 2002, p. 82-89), além de extremamente vigiado e cobrado por suas decisões, seja na imprensa, no Poder Judiciário ou na academia (RIBEIRO, 2002, p. 94-107). Inclusive, Monique Menezes identifica que (2015, p. 145) muitas vezes ocorre o oposto: "o aperfeiçoamento das regras regulatórias, em decorrência da atuação do TCU, passa despercebido pela sociedade".

Ressalte-se que o autor, no mesmo texto, afirma que as agências reguladoras sofrem cada vez mais com indicações inapropriadas de dirigentes e interferências políticas que resultam em menor "capacidade de fixar boas políticas regulatórias". Porém, critica ferozmente a atuação dos órgãos constitucional e legalmente legitimados para corrigir esses problemas (SCHIRATO, 2003, p. 272).

Schirato também contesta (2003, p. 271) a atuação dos órgãos de controle acusando-os de não dialogar da mesma forma que as agências reguladoras com os agentes do mercado regulado.

Porém, uma das virtudes da atuação dos órgãos de controle e, em especial, do TCU, é justamente sua capacidade de estabelecer diálogos institucionais mais democráti- 
cos e de fomentar o controle social, possibilitando uma maior transparência das decisões regulatórias e uma participação mais efetiva da sociedade.

Em estudo empírico acerca deste ponto, Monique Menezes demonstra (2015, p. 227) que a atuação do TCU aumenta a representatividade dos cidadãos-usuários nas arenas regulatórias, uma vez que, embora as agências tenham um mandato que exija um equilíbrio entre os interesses dos agentes econômicos, dos consumidores e do Estado, "a relação mais próxima com as concessionárias faz com que as agências regulem mais na direção das empresas, em detrimento dos usuários".

Outra crítica frequente, feita por acadêmicos, advogados e gestores das agências, é que o controle do TCU sobre os atos finalísticos das agências reguladoras seria uma indevida invasão das competências dessas entidades, causando insegurança jurídica (MENEZES, 2015, p. 35, 144-146).

Contudo, como explicitado por Menezes (2015, p. 145), tal entendimento “está em desacordo com o arcabouço constitucional do país, que claramente prevê esta forma de controle", uma vez que "nenhuma ação institucional pode ser considerada absoluta" e o TCU é a "principal instituição de controle horizontal do país". "O regime institucional do país prevê a fiscalização e a contestação, quando necessário, das decisões de todas as instituições federais, pelo TCU ou diretamente pelo Congresso".

Em um Estado Democrático de Direito que alega cumprir a Constituição vigente, não é cabível existirem espaços para decisões administrativas blindadas a qualquer tipo de controle, em especial, ao controle externo do TCU, previsto constitucionalmente. Não custa lembrar que, como ressaltado por Monique Menezes $(2015$, p. 138, 232), as agências reguladoras não estão acima ou à parte dos demais órgãos e entidades da Administração Pública, devendo, sim, sujeitar-se ao controle do Poder Judiciário e do TCU.

Também cabe recordar que o art. 49, inciso V, da Constituição Federal de 1988 prevê expressamente a possibilidade de suspensão dos atos normativos das agências reguladoras pelo Poder Legislativo, sendo que isso já ocorreu diversas vezes.

Além disso, é pacífico (MENEZES, 2015, p. 161-162) na jurisprudência do TCU que o Tribunal não pode invadir o campo de escolhas do gestor, pretendendo substituílo em suas atribuições. 0 dever constitucional do TCU é tão somente verificar se a decisão adotada está em conformidade com os parâmetros legais, em todos os aspectos, incluindo a economicidade e a eficiência. Desde o advento da CF 1988, esse controle não pode ser apenas formal, legalista ou burocrático. Cabe ao TCU aprofundar sua análise de maneira a produzir um controle eficaz, eficiente e efetivo da Administração Pública, sob pena de descumprir suas responsabilidades constitucionais. 
Nesse contexto, insere-se o controle dos atos ditos discricionários das agências reguladoras por parte do TCU. Deixar de analisar e eventualmente determinar a correção das irregularidades e ilegalidades identificadas significaria contrariar o disposto na CF e permitir a criação de espaços isolados dentro da Administração Pública que são invioláveis a qualquer tipo de controle externo efetivo, o que é incompatível com o Estado Democrático de Direito que vige no Brasil.

Entende-se que não há como definir, a priori, critérios e parâmetros rígidos para disciplinar exaustivamente o controle dos atos ditos discricionários, até porque, se fossem atos que comportassem com alguma facilidade certo tipo de categorização ou limitação objetiva de seu controle ${ }^{7}$, a própria legislação já teria estabelecido esses limites. Então, cada caso concreto deve ser analisado de forma específica e única.

Os limites que existem para o controle dos atos discricionários pelo TCU são os limites que o Direito estabelece para a própria prática desses atos. Como defendido por Di Pietro, o mérito administrativo não pode servir de álibi a justificar toda e qualquer decisão dita discricionária e blindar essa decisão de qualquer tipo de controle. É preciso analisar e avaliar, em cada caso concreto, se o ato praticado não exorbitou os limites impostos pela lei e pela Constituição.

Ao permitir tal liberdade para a Administração Pública, estar-se-ia chancelando o arbítrio e tolhendo os direitos dos cidadãos. Afinal, a finalidade da existência de órgãos dedicados precipuamente ao controle da Administração Pública, como o TCU, é garantir que os demais órgãos e entidades cumpram suas missões constitucionais e legais, em estrita observância com os limites impostos pelos constituintes e legisladores democraticamente eleitos, em prol do bem-estar da sociedade.

O TCU não existe para si próprio, não é um fim em si mesmo. Aliás, nenhum tipo de controle legal ou constitucionalmente previsto é um fim em si mesmo. A finalidade principal dos controles administrativos e judiciais é garantir o interesse público, evitando danos ao Erário.

Restringir ou inviabilizar o controle judicial e administrativo sobre os atos de qualquer órgão ou entidade, incluindo as agências reguladoras, não amplia a segurança jurídica. Pelo contrário, os efeitos da ausência de controle podem ser vislumbrados nas seguintes palavras de Luis Henrique Madalena (2017, p. 272-273):

(...) a partir do momento que o resultado da arena política [Constituição] passa a ser subvertido nas entranhas do Estado executor que deveria ser o realizador de todos os anseios consagrados naquele campo de batalha, e que tais decisões passam a ser blindadas, de um modo ou de outro, à revisão judicial sob o ponto de vista material, de seu efetivo conteúdo, o Estado Democrático

\footnotetext{
${ }^{7}$ A categorização da discricionariedade administrativa proposta por Abboud e transcrita neste artigo exemplifica essa dificuldade.
} 
de Direito transforma-se em um mero simulacro (...). (sem grifos no original)

Soma-se a isso o fato de que uma das principais conclusões da pesquisa empírica feita por Monique Menezes é justamente que a fiscalização do TCU não reduz a "autonomia técnica da agência para deliberar acerca do conteúdo regulatório, mas torna este processo mais transparente". Por sua vez, as determinações do TCU não anseiam usurpar o papel das agências em regulamentar e em definir aspectos técnicos, mas tão somente visam assinar prazo para as agências corrijam os atos e as decisões que não estão em conformidade com a lei e com os princípios do interesse público (MENEZES, 2015, p. 38-39, 145-148, 228).

Assim, conclui-se que a forma atual de atuação do Tribunal no controle dos atos discricionários das agências reguladoras está de acordo com o seu mandato constitucional de principal instituição de controle horizontal, bem como fomenta a transparência regulatória e a segurança jurídica dos setores regulados pelas agências fiscalizadas pelo TCU.

\section{A Lei 13.655/2018 e seus efeitos no ordenamento jurídico}

Fruto do projeto de lei do Senado Federal (PLS) 349/2015, renumerado como projeto de lei (PL) 7.448/2017 na sua tramitação na Câmara dos Deputados (BRASIL, 2017), a Lei 13.655/2018, de 25/4/2018, inseriu novas disposições na Lei de Introdução ao Direito Brasileiro (LINDB), com o intuito de ampliar a "segurança jurídica e eficiência na criação e na aplicação do direito público", nos termos expostos pelo próprio normativo.

Cabe recordar que tal projeto de lei gerou intensos debates jurídicos acerca da sua constitucionalidade, tendo quem questionasse até a necessidade de positivar normas consideradas tão abstratas e genéricas ${ }^{8}$. Entre a conclusão da apreciação pelo Poder Legislativo e a efetiva sanção presidencial em 25/4/2018, entidades e órgãos, como a Procuradoria-Geral da República (2018) e o TCU (2018), manifestaram-se defendendo veto total ou parcial do texto.

Uma vez sancionada, a referida lei ingressou no ordenamento jurídico e passou a produzir seus efeitos, disciplinando, entre outros aspectos, condições e requisitos

\footnotetext{
${ }^{8}$ Foram dezenas de pareceres, artigos e entrevistas publicados acerca deste tema. Para dois exemplos representativos da controvérsia, ver: a entrevista do presidente da Associação Nacional dos Procuradores da República (ANPR), José Robalinho Cavalcanti, ao Portal Jota, disponível em https://www.jota.info/justica/pl-7448-17-impunidade-26042018, em que o Procurador afirma que "o PL 7448/17 favorece a impunidade de gestores públicos e limita a atuação do Ministério Público e de Tribunais de Contas", bem como "introduz conceitos imprecisos que levariam à insegurança jurídica, já que o Judiciário levaria anos até consolidar uma jurisprudência sobre a aplicação dos termos"; e a entrevista de um dos autores do anteprojeto dessa lei, Carlos Ari Sundfeld, ao Portal Jota, disponível em https://www.jota.info/justica/carlos-ari-sundfeld-pl-7488-26042018, na qual o professor afirma que "o PL 7.448/2017 'cria proteção para o bom gestor' contra atos de 'sabotagem' que seriam praticados pela Justiça, Ministérios Públicos e Tribunal de Contas da União".
} 
mínimos que devem ser observados pelas decisões nas esferas administrativa, controladora e judicial, conforme os arts. 20, 21, 23 e 27, todos da Lei $13.655 / 2018$.

Isso significa que tanto as decisões das agências reguladoras quanto as decisões dos Tribunais de Contas estão sujeitas a esta lei. Outra implicação é que o controle externo das decisões das agências passa a ter o dever de avaliar se a Lei 13.655/2018 foi respeitada em cada ato decisório, seja vinculado ou discricionário, cabendo determinação para correções e aplicação de sanções, caso a lei seja indevidamente desrespeitada.

Tendo por base as definições e as discussões da seção deste artigo sobre a discricionariedade administrativa, observa-se que essa lei introduziu novos parâmetros para balizar a prática das decisões discricionárias.

Por exemplo, o art. 20 da Lei 13.655/2018 (BRASIL, 2018) impõe que "não se decidirá com base em valores jurídicos abstratos sem que sejam consideradas as consequências práticas da decisão". Ou seja, não basta alegar que a decisão é adotada por conveniência e oportunidade, é necessário considerar aspectos fáticos do caso concreto e avaliar cenários.

Já o art. 21 exige que as decisões indiquem de modo expresso as suas consequências jurídicas e administrativas, estabelecendo um nítido viés consequencialista, que é muito criticado quando assume um caráter utilitarista, mas que pode ser benéfico desde que as consequências sejam avaliadas "não a partir de pautas utilitárias, ou das preferências subjetivas de cada intérprete, mas com base no sistema de valores da própria Constituição" e sem contrariar os normativos expressos nos textos legais e constitucionais (SOUZA NETO; SARMENTO, 2017, p.426-430).

Aplicar essa lei exige uma completa reavaliação, por parte de todos os órgãos e entidades, de seus procedimentos decisórios, com vistas a identificar quais comandos ainda não são atendidos plenamente e, por isso, ensejam a realização de alterações internas para que o normativo seja cumprido.

Ressalte-se que, devido ao diferente grau de maturidade das instituições, muito do que está previsto na lei já era cumprido por alguns órgãos e entidades, seja por iniciativa própria, seja por força de outros diplomas legais. Assim, vislumbra-se que a adaptação à Lei 13.655/2018 será mais custosa e demorada para algumas instituições do que para outras.

De toda forma, o uso frequente de conceitos abertos e indeterminados ao longo dos dispositivos da Lei 13.655/2018, com especial destaque para o "interesse geral" como um pretenso sinônimo para interesse público, certamente provocará intensos debates em sua aplicação, talvez ainda mais intensos dos que os protagonizados entre a sua aprovação pelo Poder Legislativo e a sua sanção pela Presidência da República. 


\section{Conclusão}

A definição de discricionariedade e os limites doutrinários e jurisprudenciais admitidos para o seu controle judicial e administrativo sofreram diversas alterações ao longo do tempo, indo desde a impossibilidade de qualquer controle sobre os atos discricionários até a defesa de que a discricionariedade não existe e, por isso, não há mérito administrativo insindicável.

Seguindo a doutrina majoritária na atualidade, o TCU entende que, embora haja uma esfera de discricionariedade para a tomada de algumas decisões pelos gestores, é imprescindível que tais atos obedeçam aos limites legais e constitucionais, caso contrário configurará desvio de finalidade, abuso de poder, motivação insuficiente, entre outras ilegalidades que ensejam a aplicação de sanções e a determinação de correção.

Além disso, pesquisa empírica demonstrou que (MENEZES, 2015, p. 230) "um dos principais efeitos da atuação do TCU é na redução do excesso de discricionariedade do ente regulador, tornando o regime regulatório mais transparente e com melhor equilíbrio de interesses entre concessionários e usuários”.

Assim, como demonstrado ao longo do presente artigo, em um Estado Democrático de Direito, não só é possível, como é indispensável que haja controle (judicial e administrativo) sobre os aspectos formais e materiais dos atos discricionários, sob pena de ser conivente com o arbítrio e de permitir a erosão tanto da força normativa da Constituição quanto da própria Democracia.

\section{Referências bibliográficas}

ABBOUD, Georges. Discricionariedade administrativa e judicial. São Paulo: Editora Revista dos Tribunais, 2014, edição digital.

BRASIL Lei 221/1894. Disponível em http://www2.camara.leg.br/legin/fed/lei/1824-1899/lei-221-20-novembro-1894-540367-publicacaooriginal-40560-pl.html. Acessado em 13 jun 2018.

Projeto de lei no 7.448/2017. 2017 Disponível em http://www.camara.gov.br/proposicoesWeb/fichadetramitacao?idProposicao=2130119. Acessado em 13 jun 2018.

. Lei no 13.655/2018. 2018. Disponível em http://www.planalto.gov.br/cciviL_03/_Ato2015-2018/2018/Lei/L13655.htm. Acessado em 13 jun 2018.

CASTRO, Carlos Roberto de Siqueira. 0 devido processo legal e os princípios da razoabilidade e da proporcionalidade. 4. ed. Rio de Janeiro, RJ: Forense, 2006.

DI PIETRO, Maria Sylvia Zanella. Direito Administrativo. 30ª ed. Rio de Janeiro: ed. Forense. 2017. 
Discricionariedade administrativa na Constituição de 1988. 2ª ed. São Paulo: Atlas, 2001.

FAZIO, Giussepe. Sindicabilità e Motivazione degli Atti Amministrativi Discrezionali. A. Giuffrè Editore, 1971 apud MELLO, Celso Antônio Bandeira de. Discricionariedade e controle jurisdicional. 2. ed., 8. tiragem. São Paulo: Malheiros, 2007. p. 15.

KELSEN, Hans. Pure Theory of Law. 5a ed. New Jersey: The Lawbook Exchange, LTD. 2008.

MADALENA, Luis Henrique. A Erosão da Legalidade e a Discricionariedade Administrativa. In: STRECK, Lênio Luiz (org.). A Discricionariedade nos sistemas jurídicos contemporâneos. Salvador: ed. JusPodivm. 2017. p. 255-274.

. Discricionariedade Administrativa e Hermenêutica. Salvador: ed. JusPodivm. 2016.

MELLO, Celso Antônio Bandeira de. Discricionariedade e controle jurisdicional. 2a․ ed., 8ª tiragem. São Paulo: Malheiros, 2007.

MENEZES, Monique. Autonomia e Controle das Agências Reguladoras: o papel do Tribunal de Contas da União no arranjo regulatório brasileiro. Curitiba: ed. Ithala, 2015; Teresina: ed. Edufpi, 2015.

MOREIRA NETO, Diogo de Figueiredo. Legitimidade e discricionariedade: novas reflexões sobre os limites e controle da discricionariedade. $2^{a}$. ed. Rio de Janeiro, RJ: Forense, 1991.

PROCURADORIA-GRAL DA REPÚBLICA (PGR). Nota oficial sobre o PL 7.448/2017. Disponível em http://www.mpf.mp.br/pgr/noticias-pgr/pl-que-reduzcontrole-sobre-agentes-publicos-compromete-aplicacao-da-lei-de-improbidade-administrativa-afirma-pgr. Acessado em 13 jun 2018.

RIBEIRO, Renato Jorge Brown. O Controle Externo Federal no Brasil - uma análise do modelo de gestão frente às demandas do sistema sócio político. Dissertação de mestrado apresentada no curso de mestrado em administração pública da Escola Brasileira de Administração Pública da Fundação Getúlio Vargas (FGV). 2002.

SCHIRATO, Vitor Rhein. A deterioração do sistema regulatório brasileiro. Revista de Direito Público da Economia (RDPE). Ano 1, no 1, (jan/mar. 2003). Belo Horizonte: ed. Fórum. 2003.

SOUZA NETO, Cláudio Pereira de; SARMENTO, Daniel. Direito Constitucional: teo-

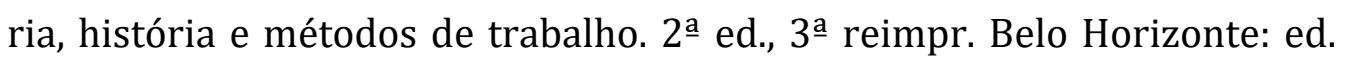
Fórum. 2017.

STRECK, Lênio Luiz. Dicionário de Hermenêutica: Quarenta temas fundamentais da Teoria do Direito à luz da Crítica Hermenêutica do Direito. Belo Horizonte: Ed. Casa do Direito, 2017. 
TRIBUNAL DE CONTAS DA UNIÃO (TCU) Parecer emitido pela Consultoria Jurídica (Conjur) do TCU sobre o PL 7.448/2017. Disponível em https://portal.tcu.gov.br/lumis/portal/file/fileDownload.jsp?fi-

leId=8A81881F62B15ED20162F95CC94B5BA4\&inline=1. Acessado em 13 jun 2018. 